\title{
Herinneringe aan vanmelewe se dae: 'n Deernisvolle huldeblyk
}

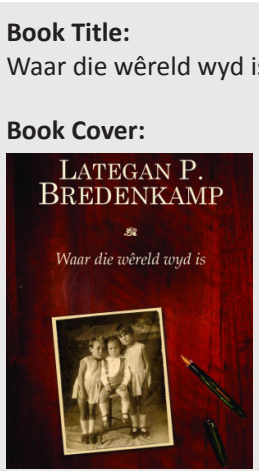

Author:

Lategan P. Bredenkamp

ISBN:

978-1-86919-358-4

Publisher:

Protea Boekhuis, Pretoria,

2010, 236 p., ZAR130.00*

*Book price at time of review

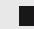

Review Title:

Herinneringe aan vanmelewe

se dae: 'n Deernisvolle

huldeblyk

Reviewer:

Linette van der Merwe ${ }^{1}$

\section{Affiliation:}

${ }^{1}$ Department of Afrikaans,

University of Pretoria,

South Africa

Email:

linette.vandermerwe@up.ac.za

Postal address:

Faculty of Education,

University of Pretoria,

Groenkloof Campus, Pretoria

0002, South Africa

How to cite this book review:

Van der Merwe, L., 2013

'Herinneringe aan vanmelewe

se dae: 'n Deernisvolle

huldeblyk', Literator 34(2), Art.

\#404, 1 page. http://dx.doi.

org/10.4102/lit.v34i2.404

\section{Copyright:}

(c) 2013. The Authors.

Licensee: AOSIS

OpenJournals. This work

is licensed under the

Creative Commons

Attribution License.

Read online:
In Waar die wêreld wyd is (2010), deel Lategan Bredenkamp sy jeugherinneringe aan sy ervaringe en belewenisse in die distrik Postmasburg met die leser. Die memoires, soos op die voorblad gekwalifiseer, vertel die herinneringsreise van kanniedood-pioniers in vroeë 1900's aan die Noord-Kaap deur die oë van die jong Bredenkamp. Die memoires word ingelei met 'Ek wil eerder my vertelling begin by my ouers en nie by myself soos ek eers van plan was om te doen nie', (bl. 9). Onthou-dinge oor sy pa, sy oupa, die familieplaas, jagtogte, sterk mans en sterk vroue kom aan die bod en word afgesluit met 'n huldeblyk aan sy ouers:

Die grootste monument vir my ouers is dat hulle net gewone ouers was, wat gedoen het wat hulle veronderstel was om te doen; ' $n$ lig vir die wêreld en die sout van die aarde was. Hulle het die stryd gestry en die wedloop voleindig. Nou lê hulle langs mekaar in die grond wat hulle so lief gehad het, op 'n plek wat hulle elke dag van die voorstoep af kon sien. En ons, hulle kinders, gedy op wat hulle ons gelaat het, wat hulle ons geleer het en die pad wat hulle vir ons oopgemaak het. (bl. 236)

Memoires is die opteken van verhale of herinneringe oor die skrywer daarvan se lewe of ' $n$ ander persoon se lewe waarby die skrywer betrokke was. Memoiresskrywers is seepgladde reisigers tussen tye - die verteller-skrywer-tyd. Die tyd waarin die opgetekende herinneringe oor 'n sekere tydperk of gedeelte van 'n lewe afspeel, onderskei memoires by uitstek van outobiografieë. Feitelike gegewens soos datums en name is van minder belang en die klem lê eerder op die weergee van die vanselfsprekende en dikwels onbenullige in vergeleke met 'n outobiografie.

Waar die wêreld wyd is (2010) bestaan uit twee dele. Deel een handel oor die vertellerskrywer se ouers en grootouers en deel twee hoofsaaklik oor sy kinderlewe tydens die depressiejare wat gekenmerk is deur 'n groot droogte. In beide die afdelings kan die leser die heen-en-terugbeweeg in tyd, soos die skrywer se herinneringe hom besoek, soms verwarrend vind en dit mag die chronologiese verloop van die teks effe kniehalter. Ook die afwesigheid van datums, name en historiese verwysings mag die leser verder verwar.

Sou die leser egter op die tweeledige indeling van die teks en op die staaltjies en vertellinge oor plekke, mense en tye fokus, behoort dit 'n onderhoudende, selfs vermaaklike leeservaring te wees, soos dié lek saam met die skape aan brak grond (bl. 13), die keer toe die magistraat en staatsaanklaer delers saam met die steler was (bl. 99), die vrou van die meulenaar wat 'n goiingsak vrou-alleen op die wa gelaai het (bl. 115) en oom Rolf se stories en grappe (ble. 126-131). Wat ook verder opval, is die vertellerskrywer se ontspanne vertelstyl en genotvolle beskrywings byvoorbeeld, "n Bobbejaan eet soos 'n hoogs bedorwe kind: Skaars word 'n vrug gehap of kees sien 'n ander een' (bl. 33) en die jagveld '... is erger as 'n beeldskone, winkende buurvrou' (bl. 98).

Bredenkamp se memoires word aangevul deur enkele foto's wat die verlede visueel oproep. Die leser kan as't ware daardie windpomp langs Kwaaitsand se dam hoor skree as die wind daardie lemme te midde van die onverbiddelike droogtes laat draai.

Bredenkamp se herinneringsreise word gepas deur ' $n$ huldeblyk aan sy ouers afgesluit. Oor sy pa sê hy: 'Hy het sy werk sò gedoen dat dit vir hom mooi moes wees' (bl. 230) en oor sy ma: 'Die plek waar jy aan haar voete gespeel het en die kos wat sy vir jou gegee het, bly vir jou die mooiste wêreld en die lekkerste kos, tot in lengte van dae' (bl. 235).

In Waar die wêreld wyd is (2010) word 'n wêreld van toeka se tyd beskryf. 'n Wêreld waar Boerematriek, ponde en pennies, plaasskole, kleilatspeel, 'n pak slae op sy tyd en kalwerliefde alledaags is. ' $n$ Wêreld wat nog bekend is aan ouer lesers en byval sal vind by diegene wat in die geskiedenis en boerdery belangstel. Ook lesers met 'n waardering en liefde vir kontreikuns sal Lategan Bredenkamp se herinneringsreise 'n deernisvolle en insiggewende leeservaring vind. 